\title{
The Global Value Chain and Internalization Theory
}

\author{
Benito, Gabriel R.G.; Petersen, Bent; Welch, Lawrence S.
}

Document Version

Accepted author manuscript

Published in:

Journal of International Business Studies

DOI:

10.1057/s41267-019-00218-8

Publication date:

2019

License

Unspecified

Citation for published version (APA):

Benito, G. R. G., Petersen, B., \& Welch, L. S. (2019). The Global Value Chain and Internalization Theory. Journal of International Business Studies, 50(8), 1414-1423. https://doi.org/10.1057/s41267-019-00218-8

Link to publication in CBS Research Portal

\section{General rights}

Copyright and moral rights for the publications made accessible in the public portal are retained by the authors and/or other copyright owners and it is a condition of accessing publications that users recognise and abide by the legal requirements associated with these rights.

Take down policy

If you believe that this document breaches copyright please contact us (research.lib@cbs.dk) providing details, and we will remove access to the work immediately and investigate your claim. 


\section{The Global Value Chain and Internalization Theory Gabriel R.G. Benito, Bent Petersen, and Lawrence S. Welch}

Journal article (Accepted version*)

\section{Please cite this article as:}

Benito, G. R. G., Petersen, B., \& Welch, L. S. (2019). The Global Value Chain and Internalization Theory. Journal of International Business Studies, 50(8), 1414-1423. https://doi.org/10.1057/s41267-019-00218-8

This is a post-peer-review, pre-copyedit version of an article published in Journal of International Business Studies. The final authenticated version is available online at:

DOI: https://doi.org/10.1057/s41267-019-00218-8

* This version of the article has been accepted for publication and undergone full peer review but has not been through the copyediting, typesetting, pagination and proofreading process, which may lead to differences between this version and the publisher's final version AKA Version of Record.

Uploaded to CBS Research Portal: May २०२० 


\author{
Gabriel R.G. Benito* \\ BI Norwegian Business School \\ N-0484 Oslo, Norway \\ Phone: +47-4641-0455 \\ gabriel.r.g.benito@bi.no
}

\title{
Bent Petersen
}

Copenhagen Business School

DK-2000 Frederiksberg, Denmark

Phone: +45-3815-2510

bp.egb@cbs.dk

\author{
Lawrence S. Welch \\ Melbourne Business School \\ Carlton, Victoria 3053, Australia \\ Phone: +61-3-9349-8454 \\ l.welch@mbs.edu \\ * Author for correspondence.
}

December 30, 2018

\section{Acknowledgements}

We thank Rajneesh Narula and two anonymous reviewers for their insightful feedback and many constructive suggestions on this work. 


\title{
THE GLOBAL VALUE CHAIN AND INTERNALIZATION THEORY
}

\begin{abstract}
In a research note in this issue, Strange and Humphrey discuss how a Global Value Chain (GVC) approach serves to usefully move internalization theory towards a better understanding of the increasingly important 'middle ground' between markets and hierarchies in the contemporary highly globalized international business scene. After a brief recount of their main arguments, we argue that their discussion needs to the extended as it does not adequately recognize important differences between internalization theory and the GVC approach. Specifically, the approaches differ on the notions of efficiency, opportunism, and level of analysis. We then argue that internalization theory can benefit from the systemic view implied in the GVC approach, and discuss the role of trust as a coordinating mechanism in international business. This leads to a more general discussion of internalization theory and the difficulty of encompassing dynamic considerations such as learning and foreign operation mode combinations and flexibility within value chain interdependencies. We conclude with a research agenda that flows from our discussion.
\end{abstract}

Keywords: Internalization theory, global value chain, multinational corporation, foreign operation modes 


\section{THE GLOBAL VALUE CHAIN AND INTERNALIZATION THEORY}

\section{INTRODUCTION}

As globalization has evolved, international business has become ever more complex and dynamic, especially in terms of where activities are undertaken (i.e. their location) and how they are organized (i.e. their governance). Just three decades ago, most international business was either cross-border trade between independent business actors, or intra-company transfers of inputs, goods, and services across integrated production systems governed by multinational corporations (MNCs). At that time, MNCs typically owned substantial parts of their industries' value systems - hereafter generally termed value chains - whenever that made sense from an efficiency point of view; i.e. when the costs (including governance costs) of conducting an activity in-house (internalization, i.e. hierarchy) were lower than the alternative outside procurement option (externalization, i.e. market).

MNCs are the focal actors in internalization theory (Buckley \& Casson, 1976; see also Narula \& Verbeke, 2015), arguably one of the core theories of international business (Grøgaard \& Verbeke, 2012). The tightly integrated multi-locational MNC is now less pronounced, at least in advanced western economies, having been surpassed by more complex and flexible location and governance patterns. Value chains are increasingly separated in space and across organizational boundaries, becoming what are called Global Value Chains (GVCs). The GVC approach provides a conceptual framework to describe, understand, and manage the increasingly disaggregated and geographically dispersed value chains of MNCs (Gereffi, Humphrey, \& Sturgeon, 2005; Laplume, Petersen, \& Pearce, 2016; Narula, 2014). As mentioned by Strange and Humphrey (2019), a range of governance forms are common in GVCs that are neither market nor hierarchy; they comprise coordination through standards, 
contracts, and alliances. Yet, MNCs are not obsolete. They are now the core actors in GVCs termed, inter alia, lead firms (Gereffi, Humphrey \& Sturgeon, 2005; Humphrey \& Schmitz, 2002) and 'orchestrating firms' (Kano, 2018) - that conduct the ever-more crucial innovation and business development activities, coordinate the multitude of dispersed operations, and end up appropriating a significant part of the value created by GVCs (Mudambi, 2008). An example is Apple which is reported to have 'captured' 58 percent of the revenue of each iPhone (Economist, 15/9/18, p.79). This is despite the efforts of multinational supplier firms such as FLEX to move up the value chain through providing services such as product design (Welch, Benito, \& Petersen, 2018).

Do such developments invalidate internalization theory, with its focus on the MNC and coordination through ownership-based control? Strange and Humphrey (2019) argue that they do not, and discuss how the GVC approach could serve to develop internalization theory towards an improved understanding of the increasingly important 'middle ground' between markets and hierarchies in the contemporary highly globalized international business scene.

While we agree with Strange and Humphrey that the GVC approach is pertinent, we argue that they underplay some important differences between internalization theory and the GVC approach, thereby failing to fully uncover how the GVC approach may further internalization theory. Specifically, we note differences regarding notions of efficiency, opportunism, and level of analysis. Navigating such differences has implications for whether and how internalization theory may benefit from the systemic view implied in the GVC approach, as well as for the role of trust as a coordinating mechanism. A clarification of the differences between the GVC approach and internalization theory also facilitates a more general discussion of internalization theory and the challenge of encompassing dynamic 
considerations such as learning and foreign operation mode combinations and flexibility within value chain interdependencies. We conclude by outlining a research agenda that flows from our discussion.

\section{COMPARING INTERNALIZATION THEORY AND THE GVC APPROACH}

In this section we outline three key ways in which internalization theory and the GVC approach differ. First, internalization theory is fundamentally a theory based on the notion of efficiency. It builds on the premise that economic actors purposefully select efficient governance modes, in the sense of carrying out business activities in ways that minimize the combined costs of production (where it is done, with what technology, and at what scale) and governing them (how they are organized, who is involved and how the involved actors are remunerated). Further, even if actors themselves were disinterested in or uninformed about efficiency, competitive forces would over time tend to drive out inefficient forms and ways of operating. Hence, efficiency is an axiom of internalization theory.

In contrast, the global value chain (GVC) approach emphasizes efficiency, but also 'power' as co-determining how transactions between economic actors are governed. Lead firms, such as Nike and Apple, are able to exercise power through market control - via advertising, branding, distribution and the like - and technological development (Mudambi, 2008). Further, the buying power of many lead firms means that they are able to apply pressure for supplier firms to undertake foreign investments that generate lower costs (Welch et al., 2018). Consequently, the GVC approach recognizes that given multiple actors, the issue of efficiency is not straightforward inasmuch as the question of 'efficiency for whom?' arises. If lead firms unceasingly appropriate a highly disproportional portion of value creation, the incentives to operate efficiently for the 'greater good' (i.e. for the GVC system as a whole) 
decreases for the other actors, to the point where efficiency has to be upheld by rigorous monitoring regimes and actors disciplined by the threat of being replaced in the case of not meeting performance demands. This may in turn discourage the potentially best performers to be part of a GVC, leaving the lead firm with an inferior pool of potential candidates when forming the GVC or making replacements.

Second, but closely related to the above, while both internalization theory and the GVC approach appear to build on a compatible set of behavioral assumptions such as intentionality, rationality, and self-interest, they seemingly play different roles in the theories. In particular, ‘strong form’ self-interest (opportunism) plays a key part in how internalization theory explains governance choices; as economic actors try to minimize the risks associated with opportunism such as hold-up, poaching, and undue appropriation of rents. Hence, efficiency implies choosing modes associated with low threat of opportunistic behavior. In contrast, in the GVC approach opportunism remains ever-present; for example, suppliers must be closely supervised and monitored to ensure satisfactory performance. Though present, opportunism nevertheless typically remains curbed; overt signs of opportunism would oblige lead firms to consider renegotiating contracts, or even threatening to terminate them. Hence, whereas internalization theory presumes ex post efficiency follows from ex ante choices regarding governance mode, the GVC approach conjectures there will be a continuous need for adjustments and changes ex post. Hence, the lead firm may suppress opportunistic inclinations among the GVC-contributory (participatory) firms for the common good (Kano, 2018).

However, in addition to being an orchestrator that both directs and disciplines the GVCcontributory firms, the lead firm may also be portrayed as a self-interest seeking economic 
actor which in an opportunistic way exploits its powerful position to achieve gains at the expense of firms kept captive in the GVC (Kaplinsky, 2000; Fitter \& Kaplinsky, 2001; Kaplinsky \& Morris, 2001). Echoing Hymer’s (1970) split view of MNCs as institutions that either provide efficiency where the market fails or seek market power for their own profitmaximization purposes, the GVC approach seems to accommodate both views depending on the interpretation. In general, the GVC approach more readily accommodates the dynamic reality of continuing adjustment of formal and informal value chain connections and arrangements in the face of economic and market processes, and governmental action. Trade measures by the Trump administration and their effect are indicative of the type of action which may need to be accommodated. For example, Harley-Davidson quickly made adjustments in its production arrangements as a result of raised costs due to US tariffs imposed on aluminum and steel imports from Europe, given the importance of the European market to the company (Economist, 9/6/18).

Third, internalization theory and the GVC approach differ in terms of analytical levels. Internalization theory aims to explain the governance mode for the activities performed in a foreign country. The GVC approach, in contrast, predicts the governance mode for activities executed in the value chain across borders. But the two theories tend to have the unit of analysis in common: Both are predicting the governance mode for the activities taken together - and not individually (Johnson, Melin, \& Whittington, 2003), which would otherwise have been more aligned with transaction cost economics with its emphasis on the individual transaction as the unit of analysis (Williamson, 1975). Although combinations of governance modes do occur within individual foreign markets (for examples, see Akbar et al., 2018; Benito, Petersen \& Welch, 2009, 2011; Hashai et al., 2010; Putzhammer et al., 2018) singular modes for combinations of activities in individual foreign markets are what entry 
mode researchers usually observe. However, where singular governance modes are the general observations in studies of entries into individual foreign markets, this one-size-fits-all approach seems at odds with realities in global value chains: It is difficult to imagine that only one governance mode would prevail in a global value chain that combines numerous and very different activities across many countries. So, when Strange and Humphrey list four non-hierarchical GVC governance modes we would assume that these are frequently used in combination, not as one-size-fits-all governance modes. The issue of singular modes versus combinations of modes is, however, never discussed, or even mentioned, in their analysis. ${ }^{1}$

A combination of modes refers to a package or grouping of supportive operation modes foreign direct investment, licensing, outsourcing, etc.; see Petersen \& Welch (2002) and Welch et al. (2018) - that are joined for the purpose of achieving certain foreign market objectives. This is not a trivial issue given the way in which firms utilize combinations of modes in achieving objectives of control, market penetration and the reduction of risk. Indeed, it is difficult with some combinations to determine what is the governance mode as all parts may play different roles while acting in unison (Benito et al., 2009, 2012; Welch et al., 2018). As a result, it is difficult to say to what extent internalization occurs or drives the combination of modes. Also, such combinations are not necessarily settled at a given point in time but are frequently built up over time in response to evolving market and organizational conditions. It may even be a moving feast as modes are added and/or deleted (Clark, Pugh, \& Mallory, 1997). This is genuinely difficult terrain for internalization theory. Lead firms may change different aspects of their governance arrangements as issues are exposed in value chain interaction dynamics. And this is against a background of many suppliers seeking to extend their role in the chain (such as FLEX, which was previously mentioned in this commentary). 


\section{EXTENDING INTERNALIZATION THEORY BY DRAWING ON GVC INSIGHTS}

Despite the noted differences, like Strange and Humphrey (2019) we think there is significant scope for interaction between internalization theory and the GVC approach. Here, we focus on two particular dimensions where internalization theory can be extended by drawing on GVC insights. One key dimension is widening internalization theory by embracing the analytical level of the GVC approach. This is, in our opinion, where the GVC approach can provide particularly valuable insights that are basically missing in internalization theory. The GVC approach takes a systemic view from the outset, giving attention to the whole set of activities that together constitute the value chain.

By taking the entire value chain across countries as the level of analysis (instead of only looking at the activities performed in individual foreign countries as in internalization theory and entry mode studies in general) the interdependencies between individual governance modes are more explicitly recognized in the GVC approach. Take, as an example, a global sourcing activity of, say, information technology (IT) in country A. The governance mode, internalized or externalized IT sourcing, not only hinges on the activities performed in that country but also on activities carried out in other countries (countries $B, C, D \ldots$ etc.). If a MNC only sources IT services in country A and finds it difficult (at least in a short or medium term perspective) to source similar IT services in other countries, the entire value chain of the MNC will be dependent on the punctual and effective delivery of IT services from the source in country $A$. The MNC is therefore likely to prefer a high-control governance mode in order to mitigate the risk of value chain disruption. Conversely, if the MNC has access to similar IT services in other countries the risk of disruption or hold-ups is limited and low-control

governance modes, and even arm’s length purchasing, are more likely to be preferred. ${ }^{2}$ Hence, 
the GVC structure or configuration to some extent determines the preferred governance mode in country $A$.

Porter's distinction between dispersed or concentrated GVC configuration (Porter, 1986) captures these cross-border interdependencies; but Porter, strangely, did not discuss the governance mode implications of these interdependencies. ${ }^{3}$ In a dispersed GVC, activities are replicated in various countries and the need for coordination and control is assumed to be low. In contrast, the MNC orchestrating a concentrated GVC subscribes to global specialization and a refined international division of labor where the individual value chain activity is carried out in one country only. The coordination and control costs are assumed to be higher than in a dispersed GVC. MNCs that orchestrate predominantly concentrated GVCs expect these relatively high governance costs to be offset by more efficient production due to spatial specialization; e.g., scale economies, labor arbitrage, access to talent pools. The cross-border interdependencies are focal in this GVC configuration and, in turn, essential to the choice of governance modes. As mentioned earlier, internalization theory and entry mode literature in general, are not as effective at capturing these cross-border interdependencies and could therefore benefit from adopting the more systemic and structural view of the GVC approach. ${ }^{4}$

Another important dimension is about characteristics of social systems, where we refer to Strange and Humphrey's mentioning of 'trust' (in a broad sense) as a GVC coordination mechanism (we consider that control mechanism is the wrong term to use here). Needless to say, many other scholars have put forward trust as a complement or substitute to other, less benevolent, inter-firm and intra-firm coordination mechanisms, such as standard routines (Lawrence \& Lorsch, 1967), output control (Ouchi \& Maguire, 1975), behavioral control (Ouchi, 1977), markets and bureaucracies (Ouchi, 1980), price and authority (Bradach \& 
Eccles, 1989), and supervision, bureaucratic monitoring control, and monetary incentive mechanisms as alternatives to 'lateral integrating mechanisms’ (O’Donnell, 2000). Above, we associated dispersed GVCs with low control governance modes. In their extreme, dispersed GVCs would not need a 'visible hand' or a lead firm for coordination: The market or price mechanism, including near perfect competition, would hold agency problems in check. ${ }^{5}$ We associated concentrated GVCs with high control governance modes and assumed that these modes will incur high governance costs (i.e. high coordination and control costs). ${ }^{6}$ However, Strange and Humphrey mention strategic alliances as one of their four GVC governance arrangements and emphasize trust between the partners as “...providing the main organizing principle rather than any form of behavioral control by one or the other.”

This leads us to challenge the argument presented above that higher control operation modes are associated with higher governance costs. We take a similar position to Strange and Humphrey when we consider the exercise of behavioral control as quite expensive in terms of governance costs. If trust to varying degrees (depending on the specific GVC context) can substitute or complement behavioral control, would that imply lower governance costs? Hence, we are recognizing trust as an important coordination mechanism and we do not agree with Williamson's dismissal of trust as a mechanism that is dependably usable in business affairs (Williamson, 1992).

Then again, we do not think that trust as a coordination mechanism is fully freed from governance costs and call for a discussion of which forms of trust that MNCs may use as a virtually free public good, and which trust forms involve high (governance) costs for MNCs. Institutional-based trust (e.g., Bachman \& Inkpen, 2011) and social capital (e.g., Coleman, 1988) would seem to belong to the first category, whereas trust in the form of 'thick personal 
trust’ (Gambetta, 1988) and bonding within and across firm boundaries (Rabbiosi, 2011; Tomassen \& Benito, 2009) are aspects that MNCs have to establish and which may involve a significant and continuing investment. ${ }^{7}$

It seems certain that the public-good type of trust (i.e. institutional-based trust and social capital) is an important coordination mechanism in a national setting. The suitability of public-good type of trust is more questionable in international settings, such as those applicable to the coordination of GVCs. So, as a general rule, a public-good type of trust is widely available for coordination of domestic business activities, but less so when these activities are global. Though, this is a general rule with important exceptions. The literature on internationalization in the context of diasporas and migrant communities (Cohen, 2008; Javorcik et al., 2011) emphasizes trust as a pervading coordination mechanism. Furthermore, research on internationalization as concerted action of firms originating from the same homecountry cluster explains the phenomenon by mimetic behavior (Aharoni, 1966), learning (Canello \& Pavone, forthcoming), or network extension (Johanson \& Mattson, 1988) that provides legitimacy and curbs information costs in an uncertain foreign business environment. However, a complementary explanation of such concerted internationalization could very well be that both institutional-based and personal trust transcends borders and constitute a low-cost coordination mechanism among internationalizing firms that originate from the same home country. On this background, one may speculate to what extent GVC coordination is based on trust forms associated with diasporas, emigrant communities, or home-grown clusters. For example, even though firms involved in particular GVCs are located in different countries, they may still trace back their origin to the same home-grown cluster; a cluster characterized by high degrees of inter-firm personal and institutional-based trust that transcends national borders. 
Another intriguing research question is to what extent trust as a GVC coordinating mechanism substitutes or complements contracts with behavioral control? Strange and Humphrey present them as substituting mechanisms - the suitability of which being contingent on the extent of power asymmetry and codifiability of buyer requirements. We recognize that Strange and Humphrey for expository reasons may have wanted to make a clear distinction between various coordination mechanisms - including trust and formal contracts. We argue though that exclusive use of one of the two coordination mechanisms may be subject to diminishing returns to scale. Hence, GVC lead firms should not rely on one coordination mechanism only, but a combination of several; e.g., formal contracts complemented by trust. Our assertion resonates with Poppo and Zenger's (2002) seminal empirical study challenging the 'substitution perspective' claiming that relational norms, such as trust, are substitutes for formal contracts (as well as vertical integration through foreign direct investment). Rather than hindering or substituting for relational norms, "well-specified contracts may actually promote more cooperative, long-term, trusting exchange relationships” (Poppo \& Zenger, 2002:708). The 'complements perspective' proposes that the combined use of contracts and relational governance promotes cooperation (Poppo \& Zenger, 2002). By specifying contractual safeguards, parties signal their intent to behave cooperatively, thus facilitating the development of relational norms. Likewise, because contracts are necessarily incomplete, relational norms and trust foster "continuance and bilateralism when change and conflict arise” (Poppo \& Zenger, 2002: 713).

More recent studies have also indicated that contract structure and relational characteristics are complements (Dyer \& Chu, 2003; Hoetker \& Mellewigt, 2009; Li, Poppo, \& Zhou, 2010; Mellewigt, Madhok, \& Weibel, 2007). In this perspective, 'well-specified contracts' facilitate 
rather than hinder relational governance, including trust-building. Formal contracts work when they aim to preserve what is important in the relational substance (Mouzas \& Ford, 2012; Stinchcombe, 2001). The complementarity essentially depends on the actual design of the formal contract. When a formal contract appears as the outcome of a strategic contracting process, it complements and even induces relational elements, thereby smoothing the functionality of complex business collaborations. So, as a final note of in our discussion of trust as a GVC coordination mechanism, we submit that a more nuanced view on the type of formal contract could contribute to the reconciliation of the apparent contradiction between the substitution and complements perspectives.

\section{FINAL REMARKS}

Strange \& Humphrey (2019) provide a stimulating discussion of the mechanics of internalization in an age of global value chains. We certainly agree with their opening premise that internalization theory has predominantly focused on MNCs’ decisions to keep certain activities and functions within corporate control by performing them in-house. Less attention has admittedly been given to the many functions and activities that while externalized in the sense of not being conducted within corporate-owned units, nevertheless remain actively governed beyond 'the invisible hand' of market coordination. Such activities constitute the evolving 'middle ground' of international business governance, and merit closer scrutiny.

Still, internalization theory is surely not silent about the 'middle ground' and as such it is hard to shed a sense of strawman tactics in Strange and Humphrey’s argument. Internalization theory has discussed contractual arrangements, strategic alliances, and various kinds of so-called 'hybrids' almost from its inception, and definitely as such forms 
proliferated in the 1980s and 1990s (Hennart, 1993; see also Buckley \& Casson, 1998). That said, internalization theory (and entry mode research largely) are deficient when it comes to taking account of governance interdependencies across borders. The systemic, cross-country view of the GVC approach is more effective in accommodating these interdependencies with implications for internalization theory and entry mode research.

Further, we call for a more nuanced discussion of the governance costs associated with different non-hierarchical governance arrangements. To what extent are coordination mechanisms in the form of trust and relational norms comparable to public goods and, as such, without opportunity costs? Is the formation of personal ties and bonding always more cost-efficient than the drafting and enforcement of formal contracts, and when are these different coordination mechanisms complements rather than substitutes (Poppo \& Zenger, 2002)? In general, we see the meeting of internalization theory and the GVC approach as a potentially fruitful line of theoretical development and research in international business studies.

An important shortcoming in internalization theory is the inability to effectively deal with the dynamics of firms' international operations. Scholars argue that offshore outsourcing should be treated as a process rather than an act (see e.g. Benito et al., 2013); and similarly, a global value chain is not static but is constantly evolving. On the one hand, the focus on the need for assured quality, reliability and efficiency at supplier firms has resulted in some lead firms seeking longer term, and closer, relationships with their suppliers. Sometimes this effectively results in quasi-integration involving lead firms' placement of their own staff at supplier firms. Such arrangements can be stable, but they also facilitate subsequent moves towards increased integration as well as disintegration; e.g. due to better access to and/or discovery of 
relevant information (Petersen, Welch, \& Benito, 2010). On the other hand, a development towards more flexible arrangements has also been noted, with lead firms concurrently sourcing from different suppliers at alternative locations (Contractor et al., 2010). As changes are made or new modes added to existing ones, more dynamic as well as more complex situations emerge, which are not adequately described and explained by a static approach to entry mode choice (Meyer \& Gelbuda, 2006; Petersen et al., 2010). While there have been many calls to 'dynamize’ internalization theory this remains to be effectively accomplished.

Our commentary points to several areas such as trust, mode combination processes and learning which relate more closely to GVC interactions. Internalization theory poorly explains the flexibility in multiple forms that international business firms seek. These aspects expose the limits of internalization explanations of GVC developments, but at the same time provide an agenda for the refurbishment of internalization theory. Strange and Humphrey (2019) provide a launching pad for extension into such uncharted territory. With respect to learning, it is useful to consider GVC interactions as a learning platform. Through trust and relationship development, and the learning which flows from such processes, coordination and control from the lead firm's perspective would seem to be enhanced, yet at a lower cost. This inevitably provides a basis for increased control via other modes. For the Danish software multinational, SimCorp, the outsourcing arrangement in Ukraine generated valuable learning about what and how to control the Ukrainian operation that they utilized in the later extension to a subsidiary investment (Benito et al., 2013).

Thus, varied elements of dynamics are at play as noted in our analysis: Mode combination adjustments and flexibility; relationship development and trust; learning; and technical adjustments. They all contribute to value chain connective efficiency, the importance of which 
increases as value chains extend in length (number of links in the chain), breadth (number of suppliers at each link in the chain), and complexity (the interdependency between the various activities done in the chain).

The above comments point to a research agenda which focuses on the dynamics and flexibility aspects of GVCs. This would shed light on how GVCs adjust over time in response to the various internal and external pressures encountered by both lead and supplier firms as well as pointing to how internalization theory might develop in a way to better cope with the reality of GVC dynamics. 


\section{REFERENCES}

Aharoni, Y. 1966. The foreign investment decision process. Boston, MA: Harvard Business School.

Akbar, Y., Balboni, B., Bortoluzzi, G., Dikova, D., \& Tracogna, A. 2018. Disentangling resource and mode escalation in the context of emerging markets: Evidence from a sample of manufacturing SMEs. Journal of International Management, 24(3): 257-270.

Asmussen, C. G., Benito, G. R. G., \& Petersen, B. 2009. Organizing foreign market activities: From entry mode choice to configuration decisions. International Business Review, 18(2): 145-155.

Bachmann, R. \& Inkpen, A. C. (2011). Understanding institutional-based trust building processes in inter-organizational relationships. Organization Studies, 32(2): 281-301.

Benito, G. R. G., Dovgan, O., Petersen, B., \& Welch, L. S. 2013. Offshore outsourcing: A dynamic operation mode perspective. Industrial Marketing Management, 42(2), 211-222.

Benito, G. R. G., Petersen, B., \& Welch, L. S. 2009. Towards more realistic conceptualisations of foreign operation modes. Journal of International Business Studies, 40(9): 1455-1470.

Benito, G. R. G., Petersen, B., \& Welch, L. S. 2011. Mode combinations and international operations: Theoretical issues and an empirical investigation. Management International Review, 51(6): 803-820.

Benito, G. R. G., Petersen, B., \& Welch, L. S. 2012. Dynamics of foreign operation modes and their combinations: Insights for international strategic management. In A. Verbeke and H. Merchant (Eds.), Handbook of research on international strategic management, pp. 93-115. Cheltenham, UK: Edward Elgar, 2012.

Bradach, J. \& Eccles, R. 1989. Price, authority, and trust: From ideal types to plural forms. Annual Review of Sociology, 15(1): 97-118. 
Buckley, P. J., \& Casson, M. C. 1976. The future of the multinational enterprise. London, UK: Macmillan.

Buckley, P. J., \& Casson, M. C. 1998. Analyzing foreign market entry strategies: Extending the internalization approach. Journal of International Business Studies, 29(3): 539-561.

Buckley, P. J., \& Hashai, N. 2004. A global system view of firm boundaries. Journal of International Business Studies, 35(1): 33-45.

Canello, J., \& Pavone, P. Forthcoming. Offshore outsourcing and backshoring in the Italian manufacturing sector: The role of learning and local spillovers. Journal of International Business Studies.

Caves, R. E., \& Mehra, S. K. 1986. Entry of foreign multinationals into US manufacturing industries. In M. E. Porter (Ed.), Competition in global industries, pp. 449-481. Boston, MA: Harvard Business School Press.

Clark, T., Pugh, D.S., \& Mallory, G. 1997. The process of internationalization in the operating firm. International Business Review, 6(6): 605-623.

Cohen, R. 2008. Global diasporas - An introduction. 2nd edition. New York, NY: Routledge.

Coleman, J. S. 1988. Social capital in the creation of human capital. American Journal of Sociology, 94: S95-S120.

Contractor, F. J., Kumar, V., Kundu, S. K., \& Pedersen, T. 2010. Reconceptualizing the firm in a world of outsourcing and offshoring: The organizational and geographical relocation of high-value company functions. Journal of Management Studies, 47(8): 1417-1433.

Demsetz, H. 1993. The theory of the firm revisited. In O. E. Williamson \& S. G. Winter (Eds.), The nature of the firm: Origins, evolution and development, pp. 159- 178. New York, NY: Oxford University Press. 
Dyer, J.H., \& Chu, W. 2003. The role of trustworthiness in reducing transaction costs and improving performance: Evidence from the United States, Japan, and Korea. Organization Science, 14(1): 57-68.

Economist. 2018. Upsetting the Apple cart, 15 September, 79.

Economist. 2018, Backfire, 9 June, 62.

Fitter, R., \& Kaplinsky, R. 2001. Who gains from product rents as the coffee market becomes more differentiated? A value chain analysis. IDS Bulletin, 32(3): 69-82.

Gambetta, D. (Ed.) 1988. Trust - Making and breaking cooperative relations. Oxford, UK: Basil Blackwell.

Gereffi, G., Humphrey, J., \& Sturgeon, T. 2005. The governance of global value chains. Review of International Political Economy, 12(1): 78-104.

Grøgaard, B., \& Verbeke, A. 2012. Twenty key hypotheses that make internalization theory the general theory of international strategic management. In A. Verbeke \& H. Merchant, (Eds.), Handbook of research on international strategic management, pp. 7-30. Cheltenham, UK: Edward Elgar.

Hashai, N., Asmussen, C. G., Benito, G. R. G., \& Petersen, B. 2010. Technological knowledge intensity and entry mode diversity. Management International Review, 50(6): 659-681.

Hennart, J.-F. 1993. Explaining the swollen middle: Why most transactions are a mix of ‘market' and 'hierarchy’. Organization Science, 4(4): 529-547.

Hoetker, G., \& Mellewigt, T. 2009. Choice and performance of governance mechanisms: Matching alliance governance to asset type. Strategic Management Journal, 30(10): 1025-1044.

Humphrey, J., \& Schmitz, H. 2002. How does insertion in global value chains affect upgrading in industrial clusters? Regional Studies, 36(9): 1017-1027. 
Hymer, S. 1970. The efficiency (contradictions) of multinational corporations. American Economic Review, 60(2): 441-448.

Javorcik, B. S., Ozden, C., Spatareanu, M., \& Neagu, C. 2011. Migrant networks and foreign direct investment. Journal of Development Economics, 94(2): 231-241.

Johnson, G., Melin, L., \& Whittington, R. 2003. Micro strategy and strategizing: Towards an activity-based view. Journal of Management Studies, 40(1): 3-22.

Johanson, J., \& Mattsson, L.G. 1988. Internationalization in industrial systems-A network approach. In N. Hood \& J.-E. Vahlne (Eds.), Strategies in global competition, pp. 303321. New York, NY: Croom Helm.

Kano, L. 2018. Global value chain governance: A relational perspective. Journal of International Business Studies, 49(6): 684-705.

Kaplinsky, R. 2000. Spreading the gains from globalisation: What can be learned from value chain analysis? Journal of Development Studies, 37(2): 117-146.

Kaplinsky, R. \& Morris, M. 2001. A manual for value chain research. Brighton: IDS, University of Sussex.

Laplume, A. O., Petersen, B., \& Pearce, J. M. 2016. Global value chains from a 3D printing perspective. Journal of International Business Studies, 47(5): 595-609.

Lawrence, P. R., \& Lorsch, J. W. 1967. Differentiation and integration in complex organizations. Administrative Science Quarterly, 12(1): 1-47.

Li, J.J., Poppo, L., \& Zhou, K.Z. 2010. Relational mechanisms, formal contracts, and local knowledge acquisition by international subsidiaries. Strategic Management Journal, 31(4): 349-370.

Mellewigt, T., Madhok, A., \& Weibel, A. 2007. Trust and formal contracts in interorganizational relationships - Substitutes and complements. Managerial and Decision Economics, 28(8): 833-847. 
Meyer, K.E., \& Gelbuda, M. 2006. Process perspectives in international business research in CEE. Management International Review, 46 (2): 143-164.

Mouzas, S., \& Ford, D. 2012. Contracts as a facilitator of resource evolution. Journal of Business Research, 65(9): 1251-1253.

Mudambi, R. 2008. Location, control and innovation in knowledge intensive industries. Journal of Economic Geography, 8(5): 699-725.

Narula, R. 2001. Choosing between internal and non-internal R\&D activities: some technological and economic factors. Technology Analysis \& Strategic Management, 13(3): 365-387.

Narula, R. 2014. Exploring the paradox of competence-creating subsidiaries: Balancing bandwidth and dispersion in MNEs. Long Range Planning, 47(1-2): 4-15.

Narula, R., \& Verbeke, A. 2015. Making internalization theory good for practice: The essence of Alan Rugman's contributions to international business. Journal of World Business, 50(4); 612-622.

O’Donnell, S. W. 2000. Managing foreign subsidiaries: agents of headquarters, or an interdependent network? Strategic Management Journal, 21(5): 525-548.

Ouchi, W. G. 1977. The relationship between organizational structure and organizational control. Administrative Science Quarterly, 22(1): 95-113.

Ouchi, W. G. 1980. Markets, bureaucracies, and clans. Administrative Science Quarterly, 25(1): 129-141.

Ouchi, W. G., \& Maguire, M. A. 1975. Organizational control: Two functions. Administrative Science Quarterly, 20(4): 559-569.

Petersen, B., \& Welch, L.S. 2002. Foreign operation mode combinations and internationalization. Journal of Business Research, 55(2): 157-162. 
Petersen, B., Welch, L.S., \& Benito, G.R.G. 2010. Managing the internalisation process. Management International Review, 50(2): 137-154.

Poppo, L., \& Zenger, T. 2002. Do formal contracts and relational governance function as substitutes or complements? Strategic Management Journal, 23(8): 707-725.

Porter, M. E. 1986. Competition in global industries: A conceptual framework. In M.E. Porter (Ed.), Competition in global industries, pp. 15-60. Boston, MA: Harvard Business School Press.

Putzhammer, M., Fainshmidt, S., Puck, J., \& Slangen, A. 2018. To elevate or to duplicate? Experiential learning, host-country institutions, and MNE post-entry commitment increase. Journal of World Business, 53(4): 568-580.

Rabbiosi, L. 2011. Subsidiary roles and reverse knowledge transfer: An investigation of the effects of coordination mechanisms. Journal of International Management, 17(2): 97113.

Stinchcombe, A.L. 2001. When formality works. Chicago, IL: University of Chicago Press. Strange, R., \& Humphrey, J. 2019. What lies between market and hierarchy? Insights from internalization theory and global value chain theory. Journal of International Business Studies, this issue.

Teece, D. J. 1996. Firm organization, industrial structure, and technological innovation. Journal of Economic Behavior \& Organization, 31(2): 193-224.

Tomassen, S., \& Benito, G. R. G. 2009. The costs of governance in international companies. International Business Review, 18(3): 292-304.

Welch, L. S., Benito, G. R. G., \& Petersen, B. 2018. Foreign Operation Methods: Theory, Analysis, Strategy, second edition. Cheltenham, UK: Edward Elgar.

Williamson, O. E. 1975. Markets and hierarchies: Analysis and antitrust implications. New York, NY: Free Press. 
Williamson, O. E. 1992. Calculativeness, trust, and economic organization. Journal of Law \& Economics, 36(1): 453-486. 


\section{ENDNOTES}

${ }^{1}$ Whether a system such as a GVC is presumed to be composed of uniform or heterogeneous governance modes is not inconsequential. Consider the same activity and location properties, i.e. what is done where, in a value system denoted $Z$. In set $H$, all activities are performed in-house, whereas in set $M$ the activities are done in some combination of in-house, contracted, and arms-length transactions. Despite the system being identical, the costs of governance (i.e. the sum of costs GC involved in managing and running a particular governance configuration) are likely to be different between sets $H\left(G C_{Z H}\right)$ and $M\left(G C_{Z M}\right)$. Set $H$ provides a unified governance structure, which facilitates coordination across activities, but is less likely to obtain economies of specialization through outsourcing of activities and arm's length purchasing of goods and services than cannot be performed or produced in-house in a cost-efficient way. Conversely, set $M$ may achieve superior performance of activities on a one-by-one basis, but is also likely to incur higher costs of coordinating activities across operationally interdependent but legally independent actors. Of course, more realistic scenarios would include additional possible differences across the two sets, especially in terms of interdependencies $(\gamma)$ across activity-location combinations. Since interdependencies affect coordination costs, in case of $\gamma>0$, it follows that $G C_{Z H} \neq G C_{Z M}$. See Asmussen, Benito \& Petersen (2009) for an elaboration of the analytics of mode configurations.

\footnotetext{
${ }^{2}$ The reasoning sketched out in this paragraph largely mirrors Teece's (1996) analysis, later extended by Narula (2001), of the organization of innovative activities. However, our emphasis here is on interdependencies across countries.
}

${ }^{3}$ On hindsight this may seem like a missed opportunity - and hence we purposely wrote "strangely" because the article by Caves and Mehra (1986), now recognized as one of the seminal empirical works about governance mode choice in international operations, appeared in that same volume, which was edited by Porter himself.

\footnotetext{
${ }^{4}$ Two notable exceptions are Asmussen et al. (2009) and Buckley and Hashai (2004). While based on internalization theory, these modelling-oriented analyses are only sporadically cited in the “mainstream” literature.
}

${ }^{5}$ Of course, one could question if such price/market coordinated business activities would qualify as a GVC in the first place, but due to limited space we will not address this definition issue. 
${ }^{6}$ Like Tomassen \& Benito (2009), we follow Demsetz (1993) and use the generic term 'governance costs' to denominate market transaction costs as well as management costs in organizations.

${ }^{7}$ Bonding efforts are particularly challenging when operations involve acquired units (Tomassen \& Benito, 2009), as MNC activities become highly dispersed (Narula, 2014), and when they involve outside actors as in the case of GVCs. There is considerable evidence of the commitment of managerial time and communication costs incurred in developing and maintaining trustful relations in various forms of foreign operations. For example, a large part of the cost of licensing arrangements is made up of communication and negotiation activities preceding an agreement and of interaction between the parties thereafter (Welch et al., 2018); see also Benito et al. (2013) which analyses the case of entry and development of operations in the Ukraine by the Danish software multinational SimCorp. Their study shows that there was a significant cost involved in communication demands and the movement of staff, in both directions between Kiev and Copenhagen, including the involvement of Danish expatriate staff in Kiev. This process initially occurred under the terms of an outsourcing arrangement, which through various stages eventually led to the establishment of a subsidiary. 